\title{
Spatial-temporal patterns of major ion chemistry and its controlling factors in the Manasarovar Basin, Tibet
}

\author{
YAO Zhijun ${ }^{1},{ }^{*}$ WANG Rui ${ }^{1,2}$, LIU Zhaofei ${ }^{1}$, WU Shanshan ${ }^{1}$, JIANG Liguang $^{1}$ \\ 1. Institute of Geographic Sciences and Natural Resources Research, CAS, Beijing 100101, China; \\ 2. University of Chinese Academy of Sciences, Beijing 100049, China
}

\begin{abstract}
The Manasarovar Basin in southern Tibet, which is considered a holy land in Buddhism, has drawn international academic attention because of its unique geographical environment. In this study, based on actual measurements of major ion concentrations in 43 water samples collected during the years 2005 and 2012, we analyzed systemically the spatialtemporal patterns of water chemistry and its controlling factors in the lake and inflowing rivers. The results reveal that the water in the Manasarovar Basin is slightly alkaline, with a pH ranging between 7.4-7.9. The amounts of total dissolved solids (TDS) in lake and river waters are approximately 325.4 and $88.7 \mathrm{mg} / \mathrm{l}$, respectively, lower than that in most of the surface waters in the Tibetan Plateau. Because of the long-term effect of evaporative crystallization, in the lake, $\mathrm{Na}^{+}$and $\mathrm{HCO}_{3}{ }^{-}$have the highest concentrations, accounting for $46.8 \%$ and $86.8 \%$ of the total cation and anion content. However, in the inflowing rivers, the dominant ions are $\mathrm{Ca}^{2+}$ and $\mathrm{HCO}_{3}{ }^{-}$, accounting for $59.6 \%$ and $75.4 \%$ of the total cation and anion content. The water exchange is insufficient for such a large lake, resulting in a remarkable spatial variation of ion composition. There are several large inflowing rivers on the north side of the lake, in which the ion concentrations are significantly higher than that on the other side of the lake, with a TDS of 468.9 and $254.9 \mathrm{mg} / \mathrm{l}$, respectively. Under the influence of complicated surroundings, the spatial variations in water chemistry are even more significant in the rivers, with upstreams exhibiting a higher ionic content. The molar ratio between $\left(\mathrm{Ca}^{2+}+\mathrm{Mg}^{2+}\right)$ and $\left(\mathrm{Na}^{+}+\mathrm{K}^{+}\right)$is much higher than 1.0, revealing that the main source of ions in the waters is carbonate weathering. Although natural processes, such as rock weathering, are the major factors controlling main ion chemistry in the basin, in the future we need to pay more attention to the anthropogenic influence.
\end{abstract}

Keywords: Manasarovar; surface water chemistry; spatial-temporal distribution; rock weathering; Tibetan Plateau

Received: 2014-11-17 Accepted: 2015-01-22

Foundation: National Natural Science Foundation of China, No.41190080; “Strategic Priority Research Program (B)” of the Chinese Academy of Sciences, No.XDB03030400

Author: Yao Zhijun (1959-), Professor, specialized in hydrology and water resources studies. E-mail: yaozj@igsnrr.ac.cn

*Corresponding author: Wang Rui (1987-), PhD Candidate, E-mail: wangr.12b@igsnrr.ac.cn 


\section{Introduction}

The main ion chemistry of surface water is affected by many factors, such as climate, geology, and human activities (Stallard and Edmond, 1983). The ion composition of a lake's water is related to the water quality of its inflowing rivers. However, because of the long-term effects of natural processes such as evaporative crystallization and rock weathering, the difference in water chemistry between a lake and its inflowing rivers increases dramatically, leading to higher concentrations of ions in the lake (Wang et al., 2010b; Zhu et al., 2010). A study on the ion chemistry of a lake catchment can benefit an understanding of the rivers supplying the lake and the environment impacting the ions in the waters. The Tibetan Plateau is very sensitive to environmental changes; therefore, the ion chemistry of plateau lakes can reflect the level of impact that climate change and human disturbance have on the environment (Mitamura et al., 2003). Limited by the severe natural conditions, the studies that aim to understand the water chemistry of inland lakes in the Tibetan Plateau are still at a basic stage of investigation. They are mostly focused on areas with convenient traffic, which are heavily disturbed by human activities, such as Lake Qinghai (Xiao et al., 2012; Xu et al., 2010), Lake Nam Co (Wang et al., 2010; Zhang et al., 2008), Lake Yamzhog Yumco (Sun et al., 2013; Zhang et al., 2012), and Lake Pumayum Co (Ju et al., 2010; Zhu et al., 2010). These studies showed that there are large variations among the ion compositions of the inland lakes on the plateau. However, generally, evaporative crystallization was shown to control the chemical composition of inland lakes, and rock weathering appeared to be the primary source of ions in their inflows (Tian et al., 2014).

The Lake Manasarovar (or Mapam Yumco) is one of three famous sacred lakes in Tibet. The lake is very important globally, because of its special religious status. However, because of several limitations, including religious traditions and geographical conditions such as high altitude, the scientific information of this area is very scarce. The first measurements of the Lake were carried out in 1907 by Sven Hedin, a Swedish geographer, who reported that the maximum and average depths of the lake were $81.8 \mathrm{~m}$ and $46 \mathrm{~m}$, respectively, and that it is situated at an altitude of $4586 \mathrm{~m}$ above sea level (Wang and Dou, 1998). He also established that the Lake Manasarovar is one that has the most abundant fresh water sources in the high altitude region, with a water storage capacity of $200 \times 10^{8} \mathrm{~m}^{3}$. The Tibetan Plateau Comprehensive Scientific Expedition, CAS, carried out another survey of the Manasarovar Basin in 1976, obtaining some valuable data about the physical and chemical properties of lake and river waters (Guan et al., 1984). Yao et al. (2009) analyzed the characteristics of the water cycle in the Manasarovar Basin using the stable isotopes $\delta \mathrm{D}$ and $\delta^{18} \mathrm{O}$, proving that the level of evaporation of the lake water is very high. Wang et al. (2013) measured the depth, water quality, and modern sedimentation rates of the Lake Manasarovar and revealed that the maximum depth and water storage of the lake in the period 2009-2012 were $72.6 \mathrm{~m}$ and $46 \times 10^{8} \mathrm{~m}^{3}$, respectively, much lower than the values recorded in 1907. In addition, glacier area reduction, lake area shrinkage, and water level decline in the basin have also been reported recently (Guo et al., 2007; Liao et al., 2013; Zhang et al., 2014). Climate warming is considered the main cause for these changes (Li et al., 2014; Ye et al., 2008). In this study, based on actual measurements conducted during different periods, an extensive analysis has been conducted in order to determine the ion chemical characteristics of lake, rivers, and precipitation waters in the Manasarovar Basin. The spatial-temporal patterns of main ion 
chemistry and the sources of ions in the surface waters were also identified. Therefore, this study is very important from a scientific and practical point of view, enriching the knowledge of lake water chemistry in a little-studied plateau area and helping to protect the Tibetan sacred lake.

\section{Study area}

The Lake Manasarovar is an inland fresh water lake, located in Burang County, Ngari Prefecture of Tibet. It lies between $30^{\circ} 34^{\prime}-30^{\circ} 47^{\prime} \mathrm{N}$ and $81^{\circ} 22^{\prime}-81^{\circ} 37^{\prime} \mathrm{E}$, and has an average altitude of $4588 \mathrm{~m}$. The lake water is clear, and the surface area of the lake is about $412 \mathrm{~km}^{2}$, with a perimeter of about $83 \mathrm{~km}$ (Figure 1). The drainage basin of the lake is situated between the Transhimalaya in the north and the Himalayas in the south, and covers a total area of $4560 \mathrm{~km}^{2}$. Mountains Kailash and Gurla Mandhata consist of glaciers and areas covered by perennial snow. Therefore, besides precipitation, glaciers and snowmelt constitute another important water source for the lake and its inflowing rivers.

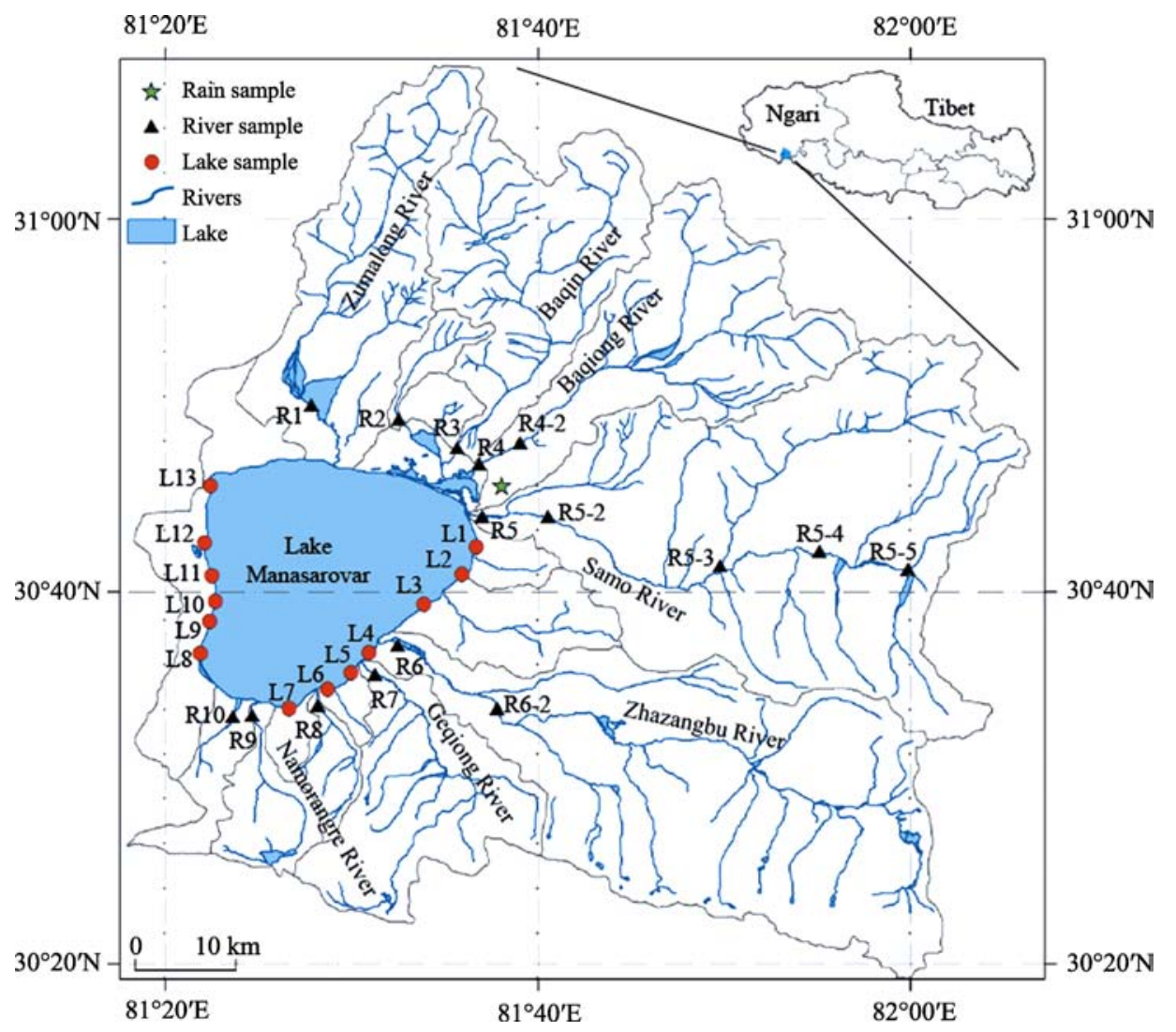

Figure 1 Drainage system of the Manasarovar Basin and the sampling sites

The Manasarovar Basin is characterized by an alpine sub-frigid arid climate zone, with no meteorological station in it. According to the reports from Burang weather station and previous studies (La et al., 2012; Wan et al., 2008; Ye et al., 2008), the average annual temperature of the basin is about $0-3.6^{\circ} \mathrm{C}$, and the average annual precipitation is approximately $130-170 \mathrm{~mm}$. Precipitation in the basin is mainly concentrated from June to August, and 
decreases from east to west and from south to north (Yao et al., 2009). The basin experiences large climate extremes within a year and, as a result, the water inflow is unevenly distributed throughout the year. In winter, both the rivers and the ground are frozen, while during the summer, river runoff into the lake is abundant. Because the basin is situated in a low-lying area and is surrounded by high mountains, the terrain is relatively closed and the land-lake breeze is easily formed in the lake area. Therefore, the wind speed is high, with a mean value of $4.4 \mathrm{~m} / \mathrm{s}$, and a daily maximum wind speed of $9.0 \mathrm{~m} / \mathrm{s}$, according to a measurement done during the month of July, 1976 (Guan et al., 1984).

\section{Sampling and analytical procedures}

Field surveys were conducted in early August 2005 and late July 2012 near the lake area in the Manasarovar Basin. A total of 43 water samples were collected, including 18 lake water samples and 25 inflowing river water samples. Because no boat was available to reach the center of the lake, the lake water samples were taken from sites about 2-3 m away from the edge of the lake. In Figure 1, five lake sampling sites (L1, L3, L5, L8, and L10) were available for both two surveys, while the sites of L4 and L13 were only available in 2005, and other sites (L2, L6, L7, L9, L11, and L12) were available in 2012. Except R2 was only available in 2005, other river sampling sites (R1, R3-R10) which are located in the estuaries of the seven main inflowing rivers and the three seasonal rivers in 2005 were repeated in 2012. Additionally, 6 samples (R4-2, R5-2-R5-5, and R6-2) were taken from upper locations on the rivers in 2012. The samples were collected at a depth of $10 \mathrm{~cm}$ and stored in $100 \mathrm{ml}$ pre-cleaned polyethylene bottles, free of air. In addition, 7 samples of precipitation water were collected with the help of local residents, from November 2004 to August 2006, including 3 snow samples.

In 2012, we collected samples from 35 sites and determined 11 parameters, such as $\mathrm{pH}$, electrical conductivity (EC), dissolved oxygen (DO), turbidity (TURB), and total dissolved solids (TDS), in situ, using a U-50 Multiparameter Water Quality Meter (Horiba Corporation, Japan), after calibrations. Afterwards, the water samples were carried back to the lab and placed in the refrigerator for cryopreservation. Then, they were left to melt naturally at room temperature before chemical measurements. Major cation $\left(\mathrm{K}^{+}, \mathrm{Na}^{+}, \mathrm{Ca}^{2+}, \mathrm{Mg}^{2+}, \mathrm{SiO}_{2}\right)$ concentrations were measured using an Inductively Coupled Plasma Optical Emission Spectrometer (ICP-OES) (PerkinElmer Corporation, USA). Anion concentrations $\left(\mathrm{SO}_{4}{ }^{2-}, \mathrm{Cl}^{-}\right.$, $\mathrm{NO}_{3}{ }^{-}$) were determined by high performance liquid chromatography (LC-10ADvp) (Shimadzu Corporation, Japan). Procedural blanks were measured in parallel to sample treatment, using identical procedures. Each calibration curve was assessed by analyzing quality control standards before, during, and after sample analysis. The precision was $\pm 2 \%$ for cations and $\pm 5 \%$ for anions. The alkalinity is represented by $\mathrm{HCO}_{3}{ }^{-}$, which was calculated using the ionic charge balance (Ju et al., 2010; Wu et al., 2008).

\section{Results and discussion}

\subsection{Major ion chemistry in the basin}

The water in the Manasarovar Basin is slightly alkaline, with an average $\mathrm{pH}$ ranging from 
7.4 to 7.9. The lake water has higher $\mathrm{pH}$ than the rivers, which exhibits increasing trends from upstream to the estuaries (Table 1). The lake water is very clear, and the TURB measurements of most river samples are less than 5 NTU, with the exception of three samples from the estuaries of R6, R7 and R10, where turbidity is higher due to the impact of rainfall erosion. The DO measurements are in the range of $33.2-45.0 \mathrm{mg} / \mathrm{l}$, and the mineralization is shown by the EC measurements varying from 205.3 to $447.8 \mu \mathrm{s} / \mathrm{cm}$. The TDS of lake waters is much higher than that of river waters, ranging from 99.7 to $307.0 \mathrm{mg} / \mathrm{l}$ in the basin (year 2012). Compared to other large lakes in the Tibetan Plateau, the TDS concentration in the Lake Manasarovar is relatively low (Table 2).

Table 1 Average content of the main chemical components of waters in the Manasarovar Basin

\begin{tabular}{|c|c|c|c|c|c|c|c|c|c|c|}
\hline & $\mathrm{K}^{+}$ & $\mathrm{Ca}^{2+}$ & $\mathrm{Na}^{+}$ & $\mathrm{Mg}^{2+}$ & $\mathrm{Cl}^{-}$ & $\mathrm{SO}_{4}^{2-}$ & $\mathrm{HCO}_{3}^{-}$ & $\mathrm{SiO}_{2}$ & TDS & $\mathrm{pH}$ \\
\hline \multicolumn{11}{|c|}{2005 measurements } \\
\hline Lake & 4.76 & 35.72 & 49.54 & 32.68 & 14.03 & 33.24 & 347.54 & - & 343.7 & - \\
\hline River estuaries & 0.84 & 16.47 & 4.70 & 4.18 & 1.68 & 23.69 & 52.28 & - & 77.7 & - \\
\hline Basin & 2.80 & 26.10 & 27.12 & 18.43 & 7.85 & 28.47 & 199.91 & - & 210.7 & - \\
\hline \multicolumn{11}{|c|}{2012 measurements } \\
\hline Lake & 6.24 & 20.11 & 54.23 & 29.28 & 14.57 & 31.03 & 299.30 & 1.87 & 307.0 & 7.85 \\
\hline River estuaries & 1.68 & 18.65 & 7.02 & 4.75 & 2.10 & 18.14 & 75.59 & 9.56 & 99.7 & 7.78 \\
\hline Upper rivers & 1.19 & 23.64 & 14.69 & 6.95 & 7.95 & 15.08 & 115.42 & 7.88 & 135.1 & 7.42 \\
\hline Basin & 3.04 & 20.80 & 25.31 & 13.66 & 8.21 & 21.42 & 163.44 & 6.44 & 180.6 & 7.68 \\
\hline \multicolumn{11}{|c|}{ Average levels between 2005-2012 measurements } \\
\hline Lake & 5.50 & 27.91 & 51.89 & 30.98 & 14.30 & 32.14 & 323.42 & - & 325.36 & - \\
\hline River estuaries & 1.26 & 17.56 & 5.86 & 4.46 & 1.89 & 20.92 & 63.94 & - & 88.70 & - \\
\hline Precipitation & 2.66 & 10.54 & 3.19 & 1.36 & 4.16 & 9.27 & 32.76 & - & 47.56 & - \\
\hline Basin & 2.92 & 23.45 & 26.22 & 16.04 & 8.03 & 24.94 & 181.67 & - & 195.65 & - \\
\hline
\end{tabular}

Note: the units of TDS and ions concentration are mg/l.

Table 2 Comparison of chemical components for lakes in the Tibetan Plateau

\begin{tabular}{lccccccccc}
\hline \multicolumn{1}{c}{ Lake } & TDS & $\mathrm{K}^{+}$ & $\mathrm{Na}^{+}$ & $\mathrm{Ca}^{2+}$ & $\mathrm{Mg}^{2+}$ & $\mathrm{Cl}^{-}$ & $\mathrm{SO}_{4}{ }^{2-}$ & $\mathrm{HCO}_{3}^{-}$ & Reference \\
\hline Manasarovar & 0.31 & 0.14 & 2.31 & 0.61 & 1.27 & 0.42 & 0.34 & 5.11 & This study \\
Qinghai & 18.05 & 4.24 & 191.8 & 0.57 & 33.44 & 226.4 & 29.52 & 29.16 & Xu et al., 2010 \\
Nam Co & 1.2 & 0.89 & 13.91 & 0.18 & 3.28 & 3.65 & 2.15 & 13.8 & Wang et al., 2010b \\
Tangra Yumco & 11.1 & - & - & - & - & - & - & - & Wang et al., 2010a \\
Zhari Namco & 7.74 & - & - & - & - & - & - & - & Wang et al., 2010a \\
Pumayum Co & 0.1 & 0.45 & - & 1.12 & 1.03 & 0.05 & 0.81 & 1.75 & Ju et al., 2010 \\
Yamzhog Yumco & 1.28 & 0.46 & 12.29 & 0.18 & 7.85 & 2.31 & 7.25 & 9.74 & Sun et al., 2013 \\
La'ang Co & 0.49 & 0.52 & 7.65 & 0.32 & 4.48 & 1.94 & 1.12 & 13.34 & Wang et al., 2013 \\
\hline
\end{tabular}

Note: The unit of TDS concentration is $\mathrm{g} / \mathrm{l}$, and the units of main ions concentration are mmol/l.

In the lake water, $\mathrm{Na}^{+}$is the most dominant cation, with a concentration of 27.38-82.84 $\mathrm{mg} / \mathrm{l}$, representing $46.8 \%$ of the total cation content. $\mathrm{Mg}^{2+}(10.13-52.32 \mathrm{mg} / \mathrm{l})$ and $\mathrm{Ca}^{2+}$ (14.35-53.63 mg/l) are found in similar concentrations. $\mathrm{K}^{+}$is the least abundant, with a concentration of $2.47-7.03 \mathrm{mg} / \mathrm{l}$, accounting for $5.0 \%$ of the total cation content. $\mathrm{HCO}_{3}{ }^{-}$is the 
the most abundant anion in the lake water, with a concentration of 150.19-504.07 mg/l, representing $75.3 \%-93.5 \%$ of the total anion content. In contrast, both $\mathrm{SO}_{4}{ }^{2-}$ and $\mathrm{Cl}^{-}$ions are less abundant, with concentrations of $15.84-57.44$ and $6.52-30.34 \mathrm{mg} / \mathrm{l}$, respectively.

The ion content of river waters is much lower than that of lake water (Table 1). The anion composition of river waters is similar with that of lake water, with anion concentrations decreasing in the order of $\mathrm{HCO}_{3}{ }^{-}>\mathrm{SO}_{4}{ }^{2-}>\mathrm{Cl}^{-}$, (27.95-192.79, 3.99-51.14, and 0.32-4.95 $\mathrm{mg} / \mathrm{l}$, respectively). $\mathrm{HCO}_{3}{ }^{-}$represents $75.4 \%$ of the total anion content in the rivers. However, the cation composition of river waters is very different from that of lake water. In the river waters, $\mathrm{Ca}^{2+}$ is the most abundant cation, representing $59.6 \%$ of the total cation content, with a concentration of $3.85-38.23 \mathrm{mg} / \mathrm{l}$. The concentration of $\mathrm{Na}^{+}$is $1.10-14.68 \mathrm{mg} / \mathrm{l}$, only accounting for $20.0 \%$ of the total cation content. $\mathrm{Mg}^{2+}$ and $\mathrm{K}^{+}$represent $16.4 \%$ and $2.0 \%$ of the total cation content, respectively.

The relative amounts of different components in water samples are shown more clearly by the ternary plots (Figure 2). In the cation ternary diagram, the lake and river water samples cluster near the $\mathrm{Na}^{+}+\mathrm{K}^{+}$and $\mathrm{Ca}^{2+}$ end-members, respectively. However, all the water samples cluster near the $\mathrm{HCO}_{3}{ }^{-}$end-member in the anion ternary diagram, revealing the significant abundance of this ion. Therefore, the Lake Manasarovar has a similar ion composition characteristic with many inland lakes in Tibet (Table 2); meanwhile, the water chemistry of its inflowing rivers is consistent with the results of Tian et al. (2014), which indicated that $\mathrm{Ca}^{2+}-\mathrm{HCO}_{3}{ }^{-}$is the main chemical type of rivers located in southern Tibet. In addition, although the ion content is relatively low, the precipitation samples have similar ion compositions with river waters, clustering near the $\mathrm{Ca}^{2+}$ and $\mathrm{HCO}_{3}{ }^{-}$end-members, revealing the significant impact of precipitation on the chemistry of river waters in the basin.

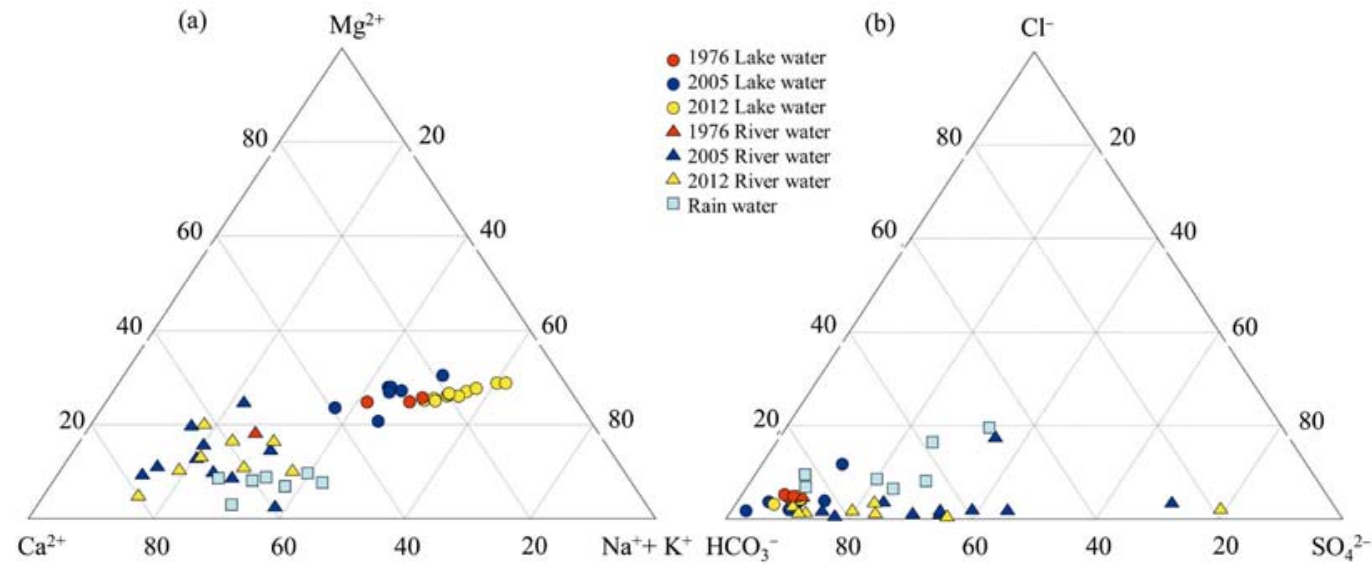

Figure 2 Ternary plots of (a) cations and (b) anions of the Lake Manasarovar, its inflowing rivers, and rain samples

\subsection{Temporal and spatial variation of major ions}

\subsubsection{Long-term evolution}

Guan et al. (1984) reported the main ion content for four sites in the Manasarovar Basin, which were measured in 1976. Because of the weaker interaction between the middle of the 
lake and the surrounding environment, the water chemistry of the lake center is relatively stable. The TDS value measured in 1976 was only $27.5 \mathrm{mg} / \mathrm{l}$ lower than the value reported by Wang et al. (2013) and taken in 2009-2010, and the average rate of change for each ion was $0.8 \%-13.6 \%$, with the largest change registered for $\mathrm{HCO}_{3}{ }^{-}$and $\mathrm{SO}_{4}{ }^{2-}$ (Table 3). The sampling site on the lake periphery used in 1976 was close to the location of sample L1 from this study. By comparing the results of water chemistry in 1976, 2005, and 2012, we found that TDS increased significantly, and the ion concentrations increased 0.8-2.1 times on average during the last four decades. Besides increasing evaporative crystallization due to climate warming (Li et al., 2014; Yao et al., 2009), anthropogenic inputs could be another factor leading to an increase in ion contents (Li et al., 2009). The amounts of $\mathrm{Ca}^{2+}, \mathrm{Mg}^{2+}$ and $\mathrm{HCO}_{3}{ }^{-}$measured in 2012 were lower than those measured in 2005, but other ions exhibited an increasing trend. Because the main sources of $\mathrm{Na}^{+}, \mathrm{Cl}^{-}$, and $\mathrm{SO}_{4}^{2-}$ are evaporites, it can be deduced that the processes of chemical weathering of evaporites are on the rise. By contrast, the effect of carbonate and silicate weathering, which mainly contributes to the $\mathrm{HCO}_{3}{ }^{-}$ in waters, is on a decreasing trend.

The TDS measurements of inflowing river water have shown an increasing trend since 1976. However, the concentrations of each ion have fluctuated, which may be related to a change in hydrothermal conditions and river discharge in the basin. Taking the sample R5 as an example (Table 3), TDS increased by $21.9 \%$ and $81.8 \%$, respectively, from 1976 to 2005 and 2012, but the contents of each ion, with the exception of $\mathrm{SO}_{4}^{2-}$, were slightly lower in 2005 , and then increased significantly in 2012, with a rate between $30.4 \%\left(\mathrm{Ca}^{2+}\right)$ and 185.0\% $\left(\mathrm{Na}^{+}\right)$. During 2005-2012, the concentrations of most of the ions in the basin river waters increased dramatically, with an average TDS amplification of $51.8 \%$, and a rate of increase for each ion ranging between $30.3 \%\left(\mathrm{Ca}^{2+}\right)$ and $124.8 \%\left(\mathrm{Na}^{+}\right)$.

Table 3 Main ions concentration in the Manasarovar Bain during different periods (mg/l)

\begin{tabular}{|c|c|c|c|c|c|c|c|c|}
\hline & $\mathrm{K}^{+}$ & $\mathrm{Ca}^{2+}$ & $\mathrm{Na}^{+}$ & $\mathrm{Mg}^{2+}$ & $\mathrm{Cl}^{-}$ & $\mathrm{SO}_{4}{ }^{2-}$ & $\mathrm{HCO}_{3}^{-}$ & TDS \\
\hline \multicolumn{9}{|l|}{ Lake center } \\
\hline $1976^{\mathrm{a}}$ & 5.92 & 24.31 & 44.05 & 25.72 & 14.83 & 26.3 & 264.66 & 277.04 \\
\hline $2009-2010^{\mathrm{b}}$ & 5.97 & 26.86 & 49.09 & 28.73 & 13.83 & 29.73 & 300.71 & 304.57 \\
\hline \multicolumn{9}{|c|}{ Lake peripheries (L1 sample for 2005 and 2012) } \\
\hline $1976^{\mathrm{a}}$ & 3.23 & 22.13 & 24.21 & 16.35 & 9.6 & 15.75 & 178.03 & 182.88 \\
\hline 2005 & 6.32 & 69.55 & 59.30 & 41.73 & 10.21 & 13.93 & 556.17 & 479.12 \\
\hline 2012 & 7.75 & 35.08 & 65.21 & 36.35 & 14.62 & 28.41 & 415.61 & 395.22 \\
\hline \multicolumn{9}{|c|}{ River estuaries (R5 sample for 2005 and 2012) } \\
\hline $1976^{\mathrm{a}}$ & 1.65 & 16.13 & 6.35 & 5.33 & 3.68 & 8.06 & 67.69 & 80.60 \\
\hline 2005 & 0.81 & 24.17 & 4.13 & 3.59 & 1.69 & 36.34 & 55.10 & 98.28 \\
\hline 2012 & 1.17 & 31.50 & 11.77 & 8.77 & 4.31 & 15.88 & 146.12 & 146.46 \\
\hline
\end{tabular}

Note: ${ }^{a}$ the data is from the reference of Guan et al. (1984); ${ }^{b}$ the data is from the reference of Wang et al. (2013)

\subsubsection{Spatial pattern}

The water exchange is insufficient in large lakes, resulting in a remarkable spatial variation of ion composition, which are impacted by the local geologic environment and the water quality of its inflowing rivers. In the Manasarovar Lake water, the spatial variation coeffi- 
cient (CV) of TDS is 0.26 , and the CV for each ion ranges from $0.25\left(\mathrm{~K}^{+}\right)$to $0.46\left(\mathrm{Ca}^{2+}\right)$. There are similar spatial distribution patterns for the $\mathrm{Mg}^{2+}$ and $\mathrm{Na}^{+}$ions, showing an increasing trend from south to north in both the east and west side of the lake (Figure 3a). For example, the equivalents of these two cations in sample L13 are three times as much as in sample L7. The amount of $\mathrm{Ca}^{2+}$ in the eastern and northern lake waters is higher than in the samples taken from the west and south sides, while the concentration of $\mathrm{K}^{+}$is slightly higher in northwest lake water samples. As the major anion, $\mathrm{HCO}_{3}{ }^{-}$is found in the highest concentrations in the northern lake water samples (L1 and L13), up to two times as much as in the samples taken from southern waters (L6-8) (Figure 3b). The concentration of $\mathrm{SO}_{4}{ }^{2-}$ is higher in the eastern lake water samples, with the highest values present in sample L13. The content of $\mathrm{Cl}^{-}$in the lake water is much lower, showing also a lower spatial variation.

(a)

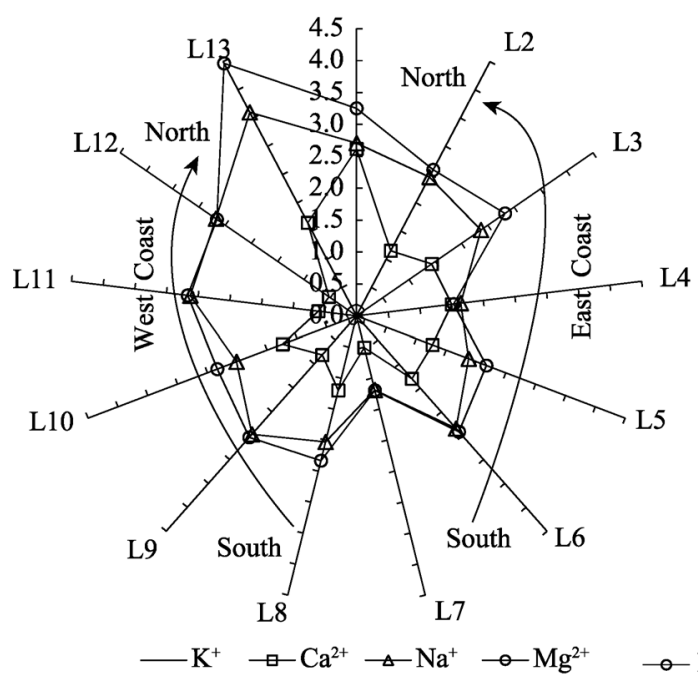

(b)

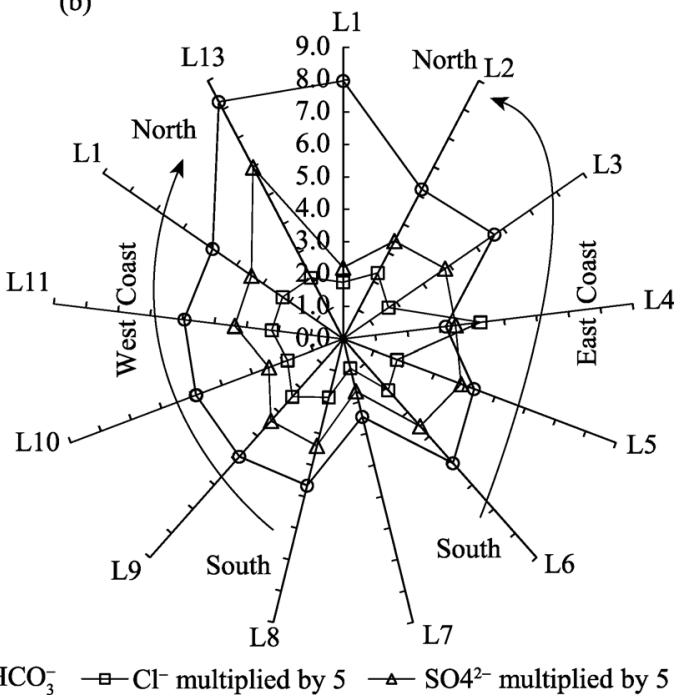

Figure 3 Concentration (meq/l) of (a) cations and (b) anions in different water samples of the Lake Manasarovar, showing the $\mathrm{Cl}^{-}$and $\mathrm{SO}_{4}^{2-}$ content expanded by five times

Above all, the ion concentrations in the northern waters of the Lake Manasarovar are significantly higher than in the southern waters, with mean TDS values of 468.9 and $254.9 \mathrm{mg} / \mathrm{l}$ in the north and south, respectively. In addition, the spatial variation of ion composition in the eastern lake waters is more prominent than that in the western waters. There are several larger rivers inflowing to the lake from the north and east (Figure 1), which is a major reason for the high amount and marked difference in ion composition between the two sides of the lake. Not only does the water quality of rivers vary, but the rivers can also carry an abundance of dissolved solids with large discharge. Especially the rivers coming from the north can include melting waters from the glaciers and snowfields far away. More ions may be carried in the processes of riverbed erosion by melting waters. Located at the west of the Lake Manasarovar, Lake La'ang Co supplies no water to it, explaining the relatively consistent characteristics of lake water chemistry on this side.

The spatial variation of water chemistry between the rivers is much higher than that of lake water, because the rivers are impacted by several geographic and hydrologic factors, such as water sources, geological condition along the way, and the magnitude of discharge. The CV of TDS in the river estuaries in the Manasarovar Basin is 0.72 , and the CV for each 
ion ranges between $0.56\left(\mathrm{~K}^{+}\right)$and $1.06\left(\mathrm{Mg}^{2+}\right)$. There are more ions in the north and northeast river waters. The average cation and anion content in the rivers R1-R5 can be 3.68 and 4.14 times as much as the concentrations recorded in the rivers R6-R10 (Figure 4). The spatial distribution pattern of the cations in rivers R1-R5 is consistent, with ion concentrations decreasing in the series R2 $>$ R3 $>$ R5 $>$ R1 $>$ R4, with the exception of the $\mathrm{Na}^{+}$ion, whose concentration is slightly higher in R3 than in R2. In rivers R6-R10, the cation content registers the lowest levels in river R8. With the exception of $\mathrm{Ca}^{2+}$, which is found in relatively higher concentrations in rivers R9 and R10, all the other cations are found in the highest concentrations in river R6, which has the largest discharge and the biggest area of drainage. The consistency between the spatial distribution patterns of $\mathrm{HCO}_{3}{ }^{-}$and the cations in river waters is very high, with the maximum and minimum values present in rivers R2 and R8, respectively. Both equivalents of $\mathrm{SO}_{4}{ }^{2-}$ and $\mathrm{Cl}^{-}$are found in the highest concentrations in river $\mathrm{R} 3$, however, the $\mathrm{SO}_{4}{ }^{2-}$ content is relatively large in rivers $\mathrm{R} 8$ and $\mathrm{R} 9$ where the $\mathrm{Cl}^{-}$ content is very low.
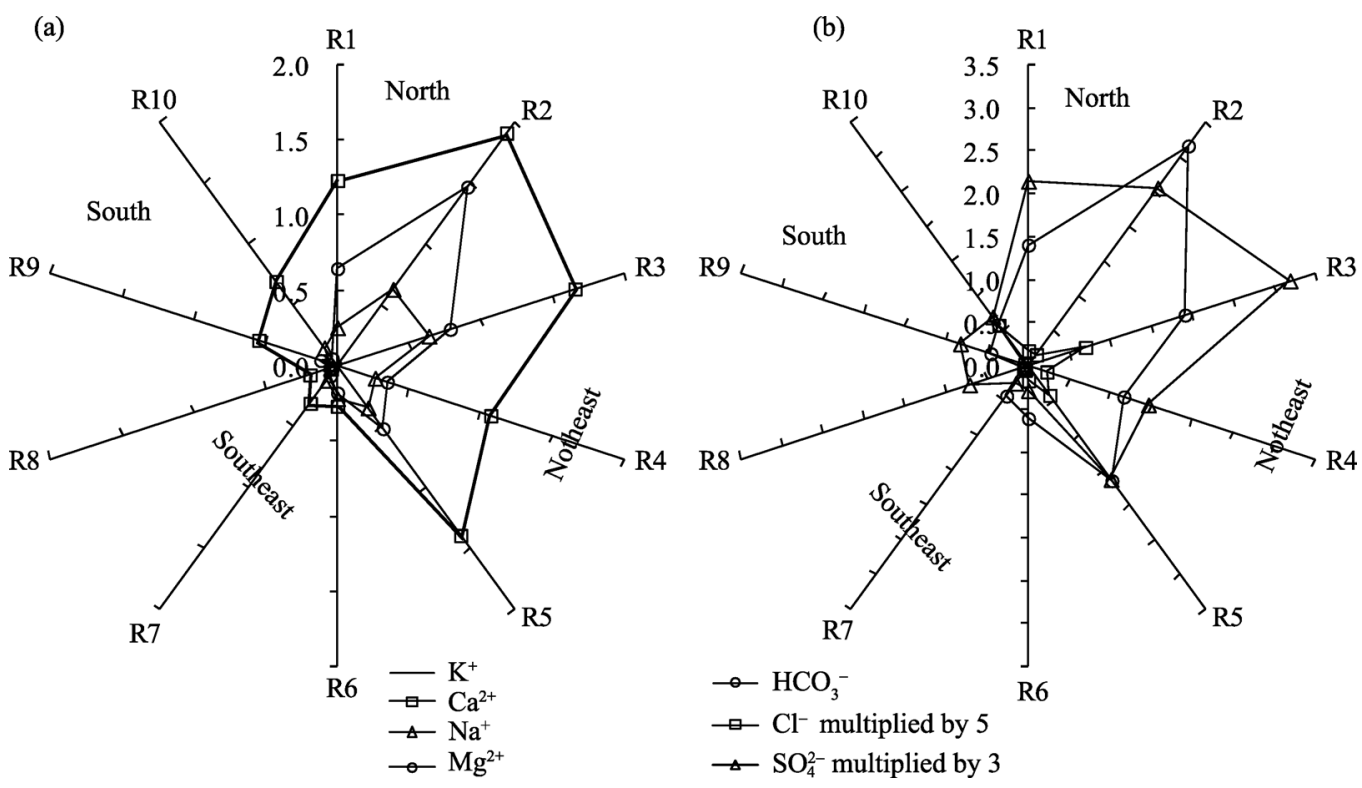

Figure 4 Equivalent (meq/l) of (a) cations and (b) anions in water samples of rivers in the Manasarovar Basin, showing the $\mathrm{Cl}^{-}$and $\mathrm{SO}_{4}{ }^{2-}$ content expanded by five and three times, respectively

In addition, according to the measurements of samples collected along river R5 in 2012, the ion contents are the highest in the upstream (R5-5) with a TDS of $205.8 \mathrm{mg} / \mathrm{l}$, and the lowest in the midstream (R5-3) with a TDS of $109.7 \mathrm{mg} / \mathrm{l}$. The ion content in river estuaries is higher than in the midstream, but lower than in the upstream. This is due to the fact that the impact of human activities such as farming and grazing is higher in upper sites and more ions are collected into the river estuaries from the tributaries. However, for a more in-depth analysis of the varying patterns of ion chemistry along the rivers, more sampling and analyses are necessary.

\subsection{Sources of solutes}

Gibbs (1970) provided a simple method to determine the relative importance of three natural factors which control surface water chemistry: evaporation and crystallization, rock weath- 


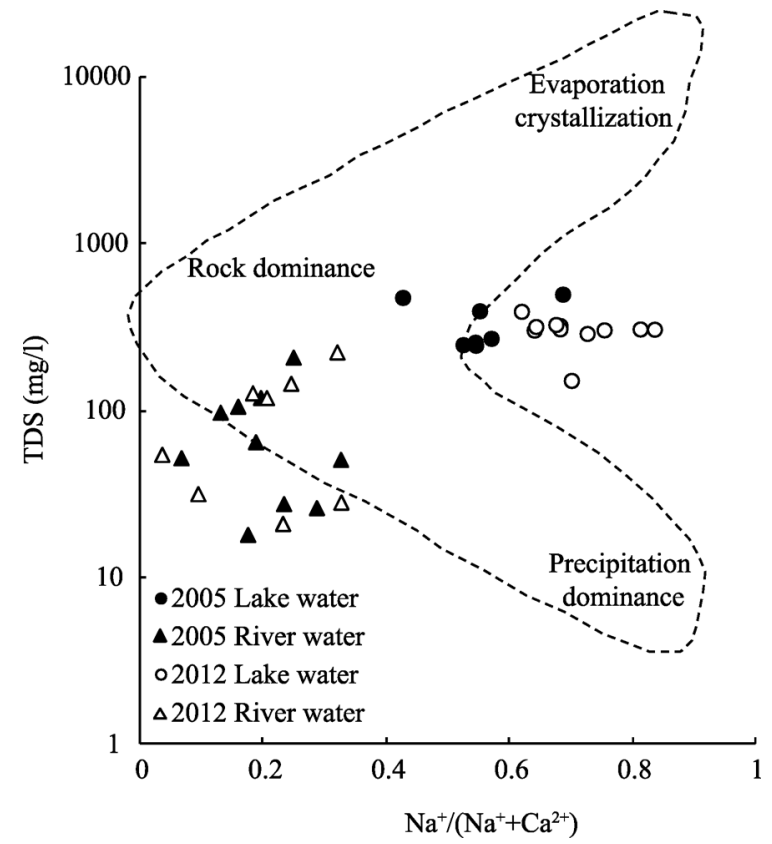

Figure 5 The Gibbs plot of the Lake Manasarovar and its flowing rivers

basin (Yin et al., 2013). ering, and precipitation. This method is based on the relationship between TDS and $\mathrm{Na}^{+} /\left(\mathrm{Na}^{+}+\mathrm{Ca}^{2+}\right)$ or TDS and $\mathrm{Cl}^{-} /\left(\mathrm{Cl}^{-}+\mathrm{HCO}_{3}^{-}\right)$. The water samples from the Manasarovar Basin are located in the middle part of the Gibbs plot (Figure 5), revealing that rock weathering is the dominant factor controlling the ion chemistry. The lake water samples are clustered in the upper right corner of the plot of the river samples, that is, the content of TDS and $\mathrm{Na}^{+}$is higher in the lake water, indicating a higher effect of evaporative crystallization on lake chemistry. In addition, the lake samples taken in 2012 have a higher ratio between $\mathrm{Na}^{+}$ and $\left(\mathrm{Na}^{+}+\mathrm{Ca}^{2+}\right)$, which shows the growing influence of increasing evaporation on water chemistry in the

\subsubsection{Anthropogenic inputs}

Human disturbances, such as agriculture and industry, are scarce in the Manasarovar Basin, due to geographical limitations and terrain conditions (Cong et al., 2010). However, the growth of tourism, religious or otherwise, might affect water chemistry in some parts of the basin. This could be the cause for the larger spatial variations in the EC measurements and ion compositions ( $\mathrm{Li}$ et al., 2009). However, in 2012, $\mathrm{NO}_{3}{ }^{-}$was not detected in the half of water samples, and in the rest of samples, its average content was between $0.57-0.93$ and 0.53-1.02 mg/l in the lake and river waters, respectively. Therefore, the $\mathrm{NO}_{3}{ }^{-}$concentration is much lower than the limit concentration stated by the National Drinking Water Standard (GB-5749) (10 mg/l). Additionally, the molar ratio of $\mathrm{Cl}^{-} / \mathrm{Na}^{+}$in all samples from the basin is less than 1.0, with low spatial variations, indicating that currently the anthropogenic input in the basin is not serious (Grosbois et al., 2000; Li et al., 2009). The ions in the Lake Manasarovar and its inflowing rivers still originate mainly from natural processes such as atmospheric migration and chemical weathering.

\subsubsection{Atmospheric inputs}

The main source of $\mathrm{Cl}^{-}$in surface waters is the sea salt cycle. As a result, $\mathrm{Cl}^{-}$concentrations decline gradually with increasing distance from the sea (Stallard and Edmond, 1981). The $\mathrm{Cl}^{-}$ions in the Tibetan Plateau should originate mainly from evaporites weathering in the basin (Chen et al., 2002, Li et al., 2009). Based on the assumption that all the $\mathrm{Cl}^{-}$in the river sample in which the $\mathrm{Cl}^{-}$concentration is the lowest originates entirely from precipitation (Hren et al., 2007), the ion contribution from atmospheric inputs to the river waters can be calculated using equation (1) (Galy and France-Lanord, 1999). The results reveal that the 
contribution of $\mathrm{K}^{+}$and $\mathrm{Cl}^{-}$from precipitation is relatively high, but the contribution rates of other ions are close to or lower than $10 \%$ (Table 4). Because lake water is subjected to strong evaporative crystallization, the ion contents are higher, and the impact of atmospheric inputs can be ignored.

$$
[\mathrm{X}]_{\text {rain }}=[\mathrm{X} / \mathrm{Cl}]_{\text {rain }} \times[\mathrm{Cl}]_{\text {rain }}
$$

where $\mathrm{X}$ represents the cations and anions; $[\mathrm{X}]_{\text {rain }}$ is the amount of each ion contributed to river waters from precipitation; $[\mathrm{X} / \mathrm{Cl}]_{\text {rain }}$ is the average molar ratio between each ion and $\mathrm{Cl}^{-} ;[\mathrm{Cl}]_{\text {rain }}$ is the contribution of $\mathrm{Cl}^{-}$to the river waters from precipitation.

Table 4 Contribution magnitude and percentage of main ions from atmospheric inputs to the river waters in the Manasarovar Basin

\begin{tabular}{lccccccc}
\hline & $\mathrm{K}^{+}$ & $\mathrm{Ca}^{2+}$ & $\mathrm{Na}^{+}$ & $\mathrm{Mg}^{2+}$ & $\mathrm{SO}_{4}{ }^{2-}$ & $\mathrm{HCO}_{3}^{-}$ & $\mathrm{Cl}^{-}$ \\
\hline Magnitude ( $\mu$ mol) & 4.90 & 19.93 & 11.01 & 4.19 & 7.20 & 40.64 & 9.11 \\
Max. percentage (\%) & 37.8 & 21.2 & 35.4 & 22.8 & 24.9 & 81.2 & 100.0 \\
Mean percentage (\%) & 21.1 & 7.1 & 9.4 & 5.7 & 6.7 & 10.8 & 47.5 \\
Min. percentage (\%) & 3.5 & 1.9 & 0.7 & 0.6 & 1.3 & 1.3 & 1.3 \\
\hline
\end{tabular}

\subsubsection{Chemical weathering inputs}

Under natural conditions, chemical weathering of different parent rocks (e.g., carbonates, silicates, and evaporites) yields several combinations of dissolved ions in the surface water. Generally, the main sources of $\mathrm{K}^{+}$and $\mathrm{Na}^{+}$are evaporite and silicate weathering. $\mathrm{Ca}^{2+}$ and $\mathrm{Mg}^{2+}$ may be derived from evaporites, silicates, or carbonates. $\mathrm{HCO}_{3}{ }^{-}$originates mostly from silicates and silicate weathering, whereas $\mathrm{Cl}^{-}$and $\mathrm{SO}_{4}{ }^{2-}$ are derived mostly from weathering and dissolution of evaporites (Li et al., 2008; Meybeck, 1987).

The molar ratio of $\mathrm{Na}^{+}$to $\mathrm{Cl}^{-}$in the lake and inflowing rivers is larger than 1.0 (Figure 6a), indicating that silicate weathering appears to have a more significant effect than halite weathering in the Manasarovar Basin. However, there are no significant correlations between $\mathrm{Si}$ and any of the $\mathrm{Na}^{+}, \mathrm{K}^{+}$, and $\mathrm{HCO}_{3}{ }^{-}$ions, revealing that the silicate contribution is also relatively low. The average ratios of alkaline earths $\left(\mathrm{Ca}^{2+}+\mathrm{Mg}^{2+}\right) /$ alkalis $\left(\mathrm{Na}^{+}+\mathrm{K}^{+}\right)$in the lake and river waters are 1.61 and 5.05, respectively (Figure 6b), which point to a stronger process of carbonate rock weathering. This was verified by Sarin et al. (1989), who reported that silicate weathering releases less $\mathrm{Ca}^{2+}$ and $\mathrm{Mg}^{2+}$ than $\mathrm{Na}^{+}$and $\mathrm{K}^{+}$. Meanwhile, all the major ions originate mainly from carbonate weathering, which is indicated by the relationship between $\mathrm{HCO}_{3}{ }^{-}$and $\mathrm{Ca}^{2+}$ (Figure 6c) and between $\mathrm{HCO}_{3}{ }^{-}$and $\left(\mathrm{Ca}^{2+}+\mathrm{Mg}^{2+}\right)$ (Figure 6d), with $\mathrm{Ca}^{2+}$, on average amounting to $25 \%$ and $85 \%$ of the $\mathrm{HCO}_{3}{ }^{-}$in the lake and rivers. However, $\left(\mathrm{Ca}^{2+}+\mathrm{Mg}^{2+}\right)$ basically balances with $\mathrm{HCO}_{3}{ }^{-}$in the rivers and balances with $74.4 \%$ of the $\mathrm{HCO}_{3}{ }^{-}$in the lake. The molar ratios of $\mathrm{Ca}^{2+} / \mathrm{SO}_{4}{ }^{2-}$ and $\mathrm{Mg}^{2+} / \mathrm{SO}_{4}{ }^{2-}$ are larger than 1.0, indicating that the contribution of sulfate weathering is not significant ( $\mathrm{Li}$ and Zhang, 2008). However, both $\mathrm{Ca}^{2+}$ and $\mathrm{Mg}^{2+}$ have good positive correlations with $\mathrm{SO}_{4}{ }^{2-}$, and the content of $\mathrm{Mg}^{2+}$ is lower than that of $\mathrm{Ca}^{2+}$ (Figure 6e), revealing that chemical weathering of sulfates such as gypsum has a certain impact on the river ion chemistry. There may be more sulfates distributing in the southeast and southern parts of the basin, as a result, the samples from rivers R6-R10 are situated on the line of $\left(\mathrm{Ca}^{2+}+\mathrm{Mg}^{2+}\right)=\left(\mathrm{HCO}_{3}{ }^{-}+\mathrm{SO}_{4}{ }^{2-}\right)$ (Figure 6f). 

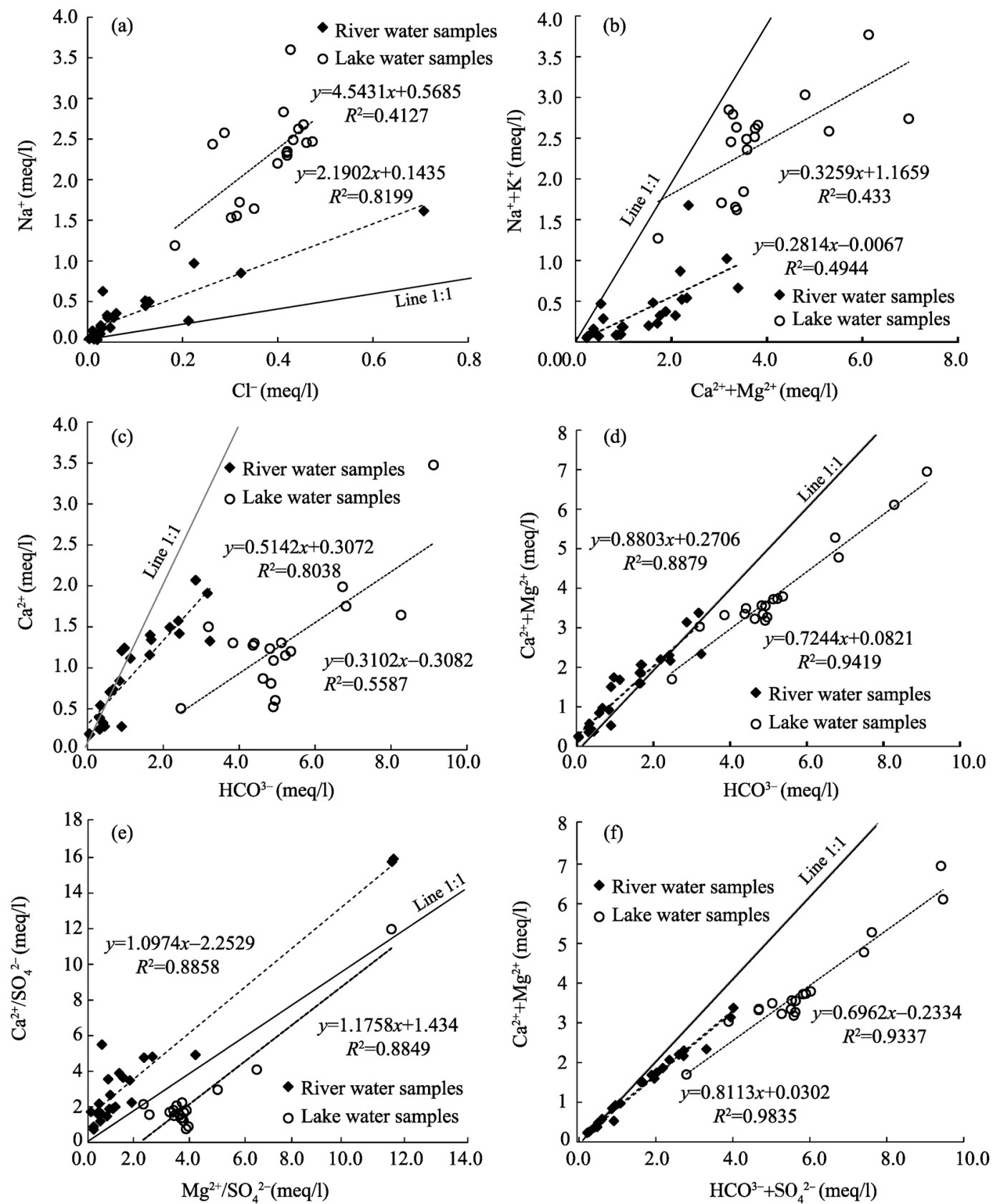

Figure 6 Equivalent comparison between different ions in the study area, showing (a) $\mathrm{Na}^{+}$vs. $\mathrm{Cl}^{-}$, (b) $\mathrm{Na}^{+}+\mathrm{K}^{+}$ vs. $\mathrm{Ca}^{2+}+\mathrm{Mg}^{2+}$, (c) $\mathrm{Ca}^{2+}$ vs. $\mathrm{HCO}_{3}^{-}$, (d) $\mathrm{Ca}^{2+}+\mathrm{Mg}^{2+}$ vs. $\mathrm{HCO}_{3}^{-}$, (e) $\mathrm{Ca}^{2+} / \mathrm{SO}_{4}{ }^{2}$ vs. $\mathrm{Mg}^{2+} / \mathrm{SO}_{4}{ }^{2+}$ and (f) $\mathrm{Ca}^{2+}+\mathrm{Mg}^{2+}$ vs. $\mathrm{HCO}_{3}^{-}+\mathrm{SO}_{4}^{2+}$

\section{Conclusions}

In this study, we have identified the spatial-temporal patterns of ion chemistry and the sources of main ions in the lake and inflowing rivers in the Manasarovar Basin. It aims to enrich the scientific understanding of the water chemistry and to protect the water resources in this sacred region. The main conclusions are listed below: 
(1) The water in the Manasarovar Basin is slightly alkaline, with a $\mathrm{pH}$ ranging between 7.4-7.9. The lake water is very clear, with lower turbidity. The TDS in lake and river waters is about 325.4 and $88.7 \mathrm{mg} / \mathrm{l}$, respectively, which is lower than in most of the surface waters in the Tibetan Plateau.

(2) Because of the long-term effect of evaporative crystallization, the concentrations of $\mathrm{Na}^{+}$and $\mathrm{HCO}_{3}{ }^{-}$are higher in the lake water, representing $46.8 \%$ and $86.8 \%$ of the total cations and anions, respectively. The ion composition of the lake water is consistent with that of the inland lakes located in southern Tibet, such as the Lake Nam Co and Lake Yamzhog Yumco. The dominant ions in the inflowing rivers are $\mathrm{Ca}^{2+}$ and $\mathrm{HCO}_{3}{ }^{-}$, accounting for $59.6 \%$ and $75.4 \%$ of the total cations and anions.

(3) The water exchange among different regions of lake and inflowing rivers is insufficient, resulting in a remarkable spatial variation of ion composition. The average CV of TDS in the lake and river waters is 0.26 and 0.72 , respectively. There are several large rivers inflowing into the lake from the north. Therefore, the ion concentrations in the north side of the lake waters are significantly higher than that on the other side, with a TDS of 468.9 and $254.9 \mathrm{mg} / \mathrm{l}$, respectively. Under the influence of complicated surroundings, the spatial variations of river water chemistry are significant, with a higher ionic content present in the upstream part of the rivers.

(4) The major factors controlling the ion chemistry in the basin are the natural processes, such as rock weathering. The high concentrations of $\mathrm{Ca}^{2+}, \mathrm{Mg}^{2+}$, and $\mathrm{HCO}_{3}{ }^{-}$in the waters reveal that the dominant source of the ions is carbonate weathering. The atmospheric factor contributes only relatively more $\mathrm{K}^{+}$and $\mathrm{Cl}^{+}$to the river waters, with the contribution rate of $21.1 \%$ and $47.5 \%$, respectively.

(5) Due to climate change, the ion contents in the surface waters in the basin have increased gradually. The TDS measurements performed after the year 2000 are 2.4 and 1.5 times as much as those of 1976, in the lake and river waters, respectively. Although the contribution of the anthropogenic inputs is not significant at the moment, the influence of human presence needs to be studied in more detail in the future.

\section{Acknowledgement}

The authors express the sincere gratitude to Dr. Liu Jian, Master Duan Rui, Master Dong Xiaohui for collection of the water samples during the year 2005, Prof. Liu Gaohuan and Ms. Jiang Yadong for participation in the field investigation in the year 2012, to Editor Zhao Xin of the Journal of Geographical Sciences for the valuable suggestions which significantly improved the quality of this paper.

\section{References}

Chen J, Wang F, Xia X et al., 2002. Major element chemistry of the Changjiang (Yangtze River). Chemical Geology, 187: 231-255.

Cong Z, Kang S, Zheng W et al., 2010. Modern process and historical reconstruction of $\mathrm{Pb}$ and $\mathrm{Hg}$ in remote areas: A critical review. Acta Geographica Sinica, 65(3): 351-360. (in Chinese)

Galy A, France-Lanord C, 1999. Weathering processes in the Ganges-Brahmaputra basin and the riverine alkalinity budget. Chemical Geology, 159: 31-60.

Gibbs R J, 1970. Mechanisms controlling world water chemistry. Science, 170(3962): 1088-1090.

Grosbois C, Negrel PH, Fouillac C et al., 2000. Dissolved load of the Loire River: chemical and isotopic characterization. Chemical Geology, 170: 179-201. 
Guan Zhihua, Chen Chuanyou, Qu Yuxiong et al. (eds.), 1984. Rivers and Lakes of Tibet. Beijing: Science Press, 169-176. (in Chinese)

Guo L, Ye Q, Yao T et al., 2007. The Glacial Landforms and the Changes of Glacier and Lake Area in the Manasarovar Basin in Tibetan Plateau Based on GIS. Journal of Glaciology and Geocryology, 29(4): 517-524. (in Chinese)

Hren M T, Chamberlain C P, Hilley G E et al., 2007. Major ion chemistry of the Yarlung Tsangpo-Brahmaputra river: Chemical weathering, erosion, and $\mathrm{CO}_{2}$ consumption in the southern Tibetan plateau and eastern syntaxis of the Himalaya. Geochimica et Cosmochimica Acta, 71: 2907-2935.

Ju J, Zhu L, Wang J et al., 2010. Water and sediment chemistry of Lake Pumayum Co, South Tibet, China: Implications for interpreting sediment carbonate. Journal of Paleolimnology, 43: 463-474.

La B, Bian D, Ci Z et al., 2012. Study on the change of lake area and its causes in the Mapangyong Co Basin in Tibet. Arid Zone Research, 29(6): 992-996. (in Chinese)

Li L, Li J, Yao X et al., 2014. Changes of the three holy lakes in recent years and quantitative analysis of the influencing factors. Quaternary International, 349: 339-345.

Li S, Xu Z, Wang H et al., 2009. Geochemistry of the upper Han River basin, China: 3. Anthropogenic inputs and chemical weathering to the dissolved load. Chemical Geology, 264: 89-95.

Li S, Zhang Q, 2008. Geochemistry of the upper Han River basin, China: 1. Spatial distribution of major ion compositions and their controlling factors. Applied Geochemistry, 23: 3535-3544.

Liao J, Shen G, Li Y, 2013. Lake variations in response to climate change in the Tibetan Plateau in the past 40 years. International Journal of Digital Earth, 6: 534-549.

Meybeck M, 1987. Global chemical weathering of surficial rocks estimated from river dissolved loads. American Journal of Science, 287: 401-428.

Mitamura O, Seike Y, Kondo K et al., 2003. First investigation of ultraoligotrophic alpine Lake Puma Yumco in the pre-Himalayas, China. Limnology, 4: 167-175.

Sarin MM, Krishnaswami S, Dilli K et al., 1989. Major ion chemistry of the Ganga-Brahmaputra river system, Weathering processes and fluxes to the Bay of Bengal. Geochimica et Cosmochimica Acta, 53(5): 997-1009.

Stallard R F, Edmond J M, 1981. Geochemistry of the Amazon 1. Precipitation chemistry and the marine contribution to the dissolved load at the time of peak discharge. Journal of Geophysical Research, 86: 9844-9858.

Stallard R F, Edmond J M, 1983. Geochemistry of Amazon. 2 The influence of geology and weathering environment on the dissolved load. Journal of Geophysical Research, 88: 9671-9688.

Sun R, Zhang X, Zheng D, 2013. Spatial variation and its causes of water chemical property in Yamzhog Yumco Basin, South Tibet. Acta Geographica Sinica, 68(1): 36-44. (in Chinese)

Tian Y, Yu C, Luo K et al., 2014. Water chemical properties and the element characteristics of natural water in Tibet, China. Acta Geographica Sinica, 69(7): 969-982. (in Chinese)

Wan W, Feng X, Xiao P et al., 2008. Differences of lake color between Mapangyongcuo Lake and La'angcuo Lake based on remote sensing. Remote Sensing Technology and Application, 23(6): 667 - 671. (in Chinese)

Wang J, Peng P, Ma Q et al., 2010a. Modern limnological features of Tangra Yumco and Zhari Namco, Tibetan Plateau. Journal of Lake Sciences, 22(4): 629-632. (in Chinese)

Wang J, Peng P, Ma Q et al., 2013. Investigation of water depth, water quality and modern sedimentation rate in Manasarovar and La'ang Co, Tibet. Journal of Lake Sciences, 25(4): 609-616. (in Chinese)

Wang J, Zhu L, Wang Y et al., 2010b. Comparisons between the chemical compositions of lake water, inflowing river water, and lake sediment in Nam Co, Central Tibetan Plateau, China and their controlling mechanisms. Journal of Great Lakes Research, 36: 587-595.

Wang Sumin, Dou Hongshen (eds.), 1998. China Lake Records. Beijing: Science Press, 403-404. (in Chinese)

Xiao J, Jin Z, Zhang F et al., 2012. Solute geochemistry and its sources of the groundwaters in the Qinghai Lake catchment, NW China. Journal of Asian Earth Sciences, 52: 21-30.

$\mathrm{Xu} \mathrm{H}$, Hou Z, An Z et al., 2010. Major ion chemistry of waters in Lake Qinghai catchments, NE Qinghai-Tibet plateau, China. Quaternary International, 212: 9-9.

Yao Zhijun, Liu Jian, Huang Heqing, 2009. Characteristics of isotope in precipitation, river water and lake water in the Manasarovar basin of Qinghai-Tibet Plateau. Environmental Geology, 57: 551-556.

Ye Q, Yao T, Chen F et al., 2008. Glacier and lake co-variations and their responses to climate change in the Mapam Yumco Basin on Tibet. Geographical Research, 27(5): 1178-1190. (in Chinese)

Yin Y, Wu S, Zhao D et al., 2013. Modeled effects of climate change on actual evapotranspiration in different eco-geographical regions in the Tibetan Plateau. Journal of Geographical Sciences, 23(2): 195-207.

Zhang Q, Kang S, Wang F et al., 2008. Major ion geochemistry of Nam Co Lake and its sources, Tibetan Plateau. Aquatic Geochemistry, 14: 321-336.

Zhang X, Sun R, Zhu L, 2012. Chemical properties and quality evaluation of lake water in the Yamzhog Yumco Basin, South Tibet. Journal of Glaciology and Geocryology, 34(4): 950-958. (in Chinese)

Zhang X, Wu Y, Zhang X, 2014. Water level variation of inland lakes on the south-central Tibetan Plateau in 1972-2012. Acta Geographica Sinica, 69(7): 993-1001. (in Chinese)

Zhu L, Ju J, Wang Y et al., 2010. Composition, spatial distribution, and environmental significance of water ions in Pumayum Co catchment, southern Tibet. Journal of Geographical Sciences, 20: 109-120. 